\title{
International Human rights law in an armed conflict: Legal perspectives on obligations of States and Extraterritoriality
}

\author{
Sardar M. A. Waqar Khan Arif ${ }^{1}$ \\ ${ }^{1}$ HOD, Department of Law, University of Kotli, Pakistan \& PhD Scholar, IIUI Pakistan-cum- \\ University of Groningen, Netherlands. \\ Email: sardarwaqarkhan@gmail.com
}

\begin{abstract}
Human rights are available to everyone on the basis of humanity. Universality, nondiscrimination, equality and inalienability are core principles governing International Human rights Law (IHRL). The law governing armed conflict or war is known as International humanitarian Law (IHL). In the case of armed conflict, IHRL poses certain obligations on states along with humanitarian obligations. In this context, this article identifies the international human rights obligations of States in armed conflict. It argues that States must respect, promote, protect and fulfill human rights obligations of individuals, in the case of armed conflict, with increasing and serious concern, by analyzing the applicable legal framework under IHRL. It also addresses the extraterritorial application of IHRL and its limitations and derogations in armed conflict. Further, it discusses contemporary challenges for States in jurisdictional applicability and implementation of IHRL. To that extent, the argument developed throughout this article is that States have obligations under IHRL, irrespective of humanitarian obligations, not only in peace situations but also in the case of war or armed conflict.
\end{abstract}

Keywords: Armed Conflict, International human rights law, Humanitarian and human rights obligations, and jurisdiction.

\section{Introduction}

The purpose of IHRL is promotion and protection of human rights of people which are available to them on the basis of humanity. It is articulated in the Universal Declaration of Human Rights (UDHR) which states that: "all human beings are born free and equal in dignity and rights". ${ }^{1}$ The recognition and protection of rights is given by IHRL and it central to its debate. Although States (only) are subjects of International law in a traditional sense but IHRL recognizes the entitlement of rights and dignity of "everyone" and not only of States

${ }^{1}$ Article 1 of Universal Declaration of Human Rights, (1948), G.A. Res. 217 (III), U.N. Doc. A/801, 10 December, (1948). 
alone. By virtue of such entitlement individuals also fall under the category of subjects. ${ }^{2}$ Such recognition and protection of fundamental human rights and fundamental freedoms is envisaged in human rights instruments. These include Charters, Covenants, Conventions/treaties, Declarations and protocols. Such recognition also extends to various regions of the world. ${ }^{3}$ For instance, the UDHR, International Covenant on Civil and political rights (ICCPR) and International Covenant on Economic, Social and Cultural rights (ICESCR). These three instruments are also known as "International Bill of Human rights". The recognition and protection of rights is universal and available to anywhere and everyone is entitled, irrespective of race, color, sex, religion and language. States which are parties to human rights instruments are obliged to protect rights of individuals worldwide. ${ }^{4}$

However, even non-state parties or non-signatories have obligations under customary IHRL. The core obligations imposed by IHRL includes first, obligation to respect, second, obligation to Promote, third, obligation to protect and finally, obligation to fulfill. "States, as the governing power within a recognized set of geographic borders, are normally tasked with protecting these fundamental rights", is the principle of IHRL which binds states. ${ }^{5}$

The UDHR is the most important document of IHRL. Although it is declaration that is non-binding but enshrines fundamental human rights which are universal and available to everyone. The ICCPR and ICESCR are further extension and expansion of UDHR. The UDHR was designed as a result of great massacre and gross loss of humanity in World WarII. The UDHR was drafted by States keeping in view the nature of violence against humanity which is in fact harmful. Initially, the idea of human rights is given in the UN charter in 1945. However, later the UDHR was adopted by General Assembly of UN in 1948. The UDHR has settled common standard for all and prohibited use of force or violence by one state against another state. It focused on elimination of violence and protection of basic human rights of mankind. ${ }^{6}$ The protection of human rights is inherent and violation of human rights of individuals is prohibited. ${ }^{7}$ For example, article 2 (b) of the UDHR states that:

No distinction shall be made on the basis of the political, jurisdictional or international status of the country or territory to which a person belongs,

${ }^{2}$ Filartiga v. Pena-Irala, 630 F.2d 876, 883 (2d Cir. 1980) decided by US District Court.

${ }^{3}$ Article 3 of Arab Charter on Human Rights, League of Arab States, 22 May, (2004).

${ }^{4}$ Article 4 of International Covenant on Civil and Political Rights, 16 December, (1966).

${ }^{5}$ Al-Skeini and others vs. United Kingdom, Application no. 55721/07, decided by ECHR on 7 July, (2011), pp.74-80.

${ }^{6}$ Preamble to Universal Declaration of Human Rights (1948).

7 Christopher Mccrudden, "Human dignity and Judicial Interpretation of Human rights", The European Journal of International Law, (2008), p656. 
whether it is independent, trust, non-self-governing or under any other limitation of sovereignty.

Because of universality and inherent nature of IHRL, it seems that protection is not only given to member states but it also extends to non-state actors, organizations, administrative authorities and more precisely individuals. While States are obliged to take necessary steps and measures for implementation of human rights instruments. In this context, nevertheless, the UN has focused on the applicability of IHRL and protection of fundamental human rights "without distinction based on the political status of countries or territories." ${ }^{8}$ The UDHR is thus "a common standard of achievement for all peoples and all nations."

This article is divided into IX Sections. As the core of article is to identify obligations of states in armed conflict under IHRL and application of IHRL in armed conflict, the law directly relevant to armed conflict, such as, IHL cannot be ignored. In this context, Section I is introductory. Section II refers to the nature of relationship between IHL or law of armed conflict and IHRL. The examination of relationship is necessary in order to apprise the reader about the relationship of both bodies of law. It will also create context for further discussion. Section III addresses the core of the law of armed conflict in which the relevant laws are highlighted. Given the core of law of armed conflict, Section IV analyses the application of IHRL in armed conflict. It analyses the legal framework of IHRL in relation to States obligations in armed conflict and discusses that what limitations and derogations are possible under IHRL?

Section V describes the core human rights obligations of States in armed conflict. In line with identified obligations of states under IHRL, Section VI and VII addresses the question of extraterritorial application of IHRL by focusing on judgments of International Court of Justice (ICJ), respectively. Based on the findings, Section VIII highlights challenges for States in implementation of IHRL. Finally, conclusions are drawn up in the last section.

As extending application of IHRL in an armed conflict is growing debate, the outcome of the article would be a contribution in the field of international law under which various questions are answered by analyzing the relevant provisions. These questions include, What are the core human rights obligations in an armed conflict? What is the nature of relationship between IHL and IHRL? What is the core of an armed conflict? These three questions are academic and based on historic approach.

${ }^{8}$ Resolution of UNGA, No: 217 D (III) of 10 December, (1948) on "Publicity to be given to the Universal Declaration of Human Rights." 
However, in terms of practical sense, this article addresses questions which need elaboration. These include, How the provisions of IHRL apply in an armed conflict given the IHL is specifically designed to regulate armed conflicts? If IHRL apply, are there any limitations or derogations to it? Further, what is legal position of extra-territorial application of IHRL? These questions are addressed in practical context by analyzing relevant laws and decisions of International Courts. It also addresses challenges for its true implementation in letter and spirit.

\section{The nature of relationship between IHL and IHRL}

IHL is specifically designed for armed conflict and it applies during armed conflict whereas IHRL is designed to protect rights of individuals at all times. It includes armed conflict as well. The terms Lex Specialis and Lex Generalis are used for both bodies of law. The former covers IHL and later deals with IHRL. Because of the different nature of both bodies of law there exists conflict or clashes in application. However, there is interplay between both bodies of law and principle of complementarity comes into play in some respects for application of IHL and IHRL in armed conflict. The relationship between IHL and IHRL cannot be denied because of complementarity between IHL and IHRL.

In an armed conflict, IHL is the core law whereas IHRL remains applicable because of its universality and general nature. It is also well established that in the case of conflict between General and Special law, the superior or primary law will be special law. So IHL prevails in times of armed conflict. However, it does not mean that, due to speciality of IHL, IHRL do not apply at all in times of armed conflict. Provisions of IHRL remain applicable where IHL is silent and States have obligations under IHRL because of its customary principles.

The purpose of IHRL is to protect rights of individuals and is designed to prevent states for abusing or violation of provisions of International law. Thus, the relationship between both bodies of law cannot be ignored in an armed conflict. Although IHL has precedence in its application in armed conflict but IHRL also continues to apply. ${ }^{9}$ IHL is nonderogable and binding on States in times of armed conflict which makes it more protective and shielding than IHRL. ${ }^{10}$ The provisions of IHL and IHRL are binding on UN and States in all respects. IHL creates obligations on States in all respects in times of armed conflict and

\footnotetext{
${ }^{9}$ Hans-Peter Gasser, "International Humanitarian Law and Human Rights Law in Non-International Armed Conflict: Joint Venture or Mutual Exclusion?", Year book of international law 149, 45 German, (2002), pp149-62.

${ }^{10}$ Louis B. Sohn, "The new International law: Protection of the rights of individuals rather than States", The American University Law Review, (1982), p7.
} 
such obligations are also advanced by IHRL. It is because of the general nature and scope of provisions of IHRL. ${ }^{11}$ IHRL continues to apply in an armed conflict and states are obliged not to violate provisions of both bodies of International law.

\section{The Core of the Law of Armed Conflict}

The core of the law of armed conflict is IHL which is enshrined in Four Geneva Conventions of 1949 and additional protocols of $1977^{12}$. Along with IHL, the human rights instruments are also applicable in times of armed conflict. Nothing in IHRL is provided to neglect its application in armed conflict. Indeed, both bodies of law, such as, IHL and IHRL, continue to apply in an armed conflict complementarily. Both create obligations on States. In terms of application of IHRL, numerous examples defended its applicability in armed conflict. For instance, the provisions of ICCPR, which is human rights instrument, continues to apply in an armed conflict irrespective of application of IHL as recalled by the Human Rights Committee (HRC), in its general comments Nos. 29 (2001) and 31 (2004). ${ }^{13}$ The IHL and IHRL are complementary and both apply in times of armed conflict. The protection given by IHRL is fundamental and cannot be ignored in times of armed conflict as acknowledged by the Human Rights Council in its resolution 9/9.

Although IHL and IHRL have different historical roots but both share a common concern, such as, protection of individuals and respect for humanity worldwide. Both aim to protect well-being of the individuals. ${ }^{14}$ The bulk of obligations crated by both bodies of law are envisaged in International conventions/treaties, declarations, covenants and protocols. Such obligations are also advanced by customary international law. The elements of State practice and belief or opinio Juris, that practice is compulsory bind states under customary IHRL. ${ }^{15}$ By evaluating the texts of IHL and IHRL, it is deduced that both are mutually enforceable and apply complementarily in an armed conflict. ${ }^{16}$

\footnotetext{
${ }^{11}$ Article 52 of the ICCPR, (1966), G.A. Res. 2200A (XXI), Supp. No. 16, U.N. Doc. A/6316, 16 December, (1966)

12 These Conventions are adopted in 1949. First, GC-I relates to wounded and sick at the battlefield; second, GC-II relates to wounded and sick at sea; third, GC-III relates to Prisoners of War and Fourth, GC-IV relates to Civilians. In addition, Additional Protocols to these Conventions are adopted in 1977. AP-I relates to International armed conflicts (IAC) and AP-II relates to Non-international armed conflict (NIAC).

${ }^{13}$ Human rights Committee (HRC), General Comments Nos. 29 (2001) on states of emergency, para. 3, and 31 (2004) on the nature of the general legal obligation imposed on States Parties to the Covenant, para. 11.

14 The principle of respect for human dignity is the basic underpinning of both IHL and IHRL as mentioned in Prosecutor v. Anto Furundzija, Case No. IT-95-17/1-T, Judgement of 10 December, (1998), para. 183.

15 The decision of the ICJ on the North Sea Continental Shelf cases, I.C.J. Reports (1969), p3.

16 Report of HRC (A/HRC/11/31, para. 5).The Human rights Council acknowledged that IHL and IHRL were complementary and mutually reinforcing.
} 


\section{Application of Human rights law in armed conflict}

In terms of application of IHRL in an armed conflict, it is well established that the obligations envisaged in human rights instruments are universal and inherent to all human beings. It is also established that the provisions of IHRL remain applicable in times of war or an armed conflict. Though IHL is considered as Lex Specialis and has precedence in its applicability in an armed conflict but the entitlements and protections important and cannot be ignored. Even in situations of Belligerent occupation or prolonged occupation the provisions of customary IHRL are binding on states. ${ }^{17}$

The obligations are incumbent on States directly and traditionally IHRL only binds States. However, it extends to non-state actors and individuals as well. The provisions are not directly binding on individuals but they fall under the ambit of States and have obligations too. In this context, States have obligations under IHRL to prevent individuals from committing crimes, such as, murder, torture etc. ${ }^{18}$ It seems that individuals also have responsibilities and protections under IHRL and states only are not subject of IHRL.

In an armed conflict, individuals are protected by IHL and IHRL in certain circumstances. IHL exclusively deals with certain aspects/matters, such as, direct participation in hostilities, treatment of wounded and sick. However, on the other hand, certain aspects, such as, the right to assembly, strike, freedom of movement and right to life are governed by IHRL. It is interesting to note that certain matters are covered by both bodies of law mutually, for instance, the prohibition on torture. ${ }^{19}$ Thus rules and standards of both bodies of law apply in different situations and it varies from situation to situation in an armed conflict.

\section{A. Legal framework under IHRL}

The primary sources of IHRL are UDHR, ICCPR and ICESCR along with other human rights instruments. ${ }^{20}$ The obligations posed by IHRL are universal, inalienable, nondiscriminatory and available to all. Along with obligations of universal human rights

${ }_{17}$ Advisory opinion of ICJ on Legality of the Threat or Use of Nuclear Weapons, Advisory Opinion, ICJ Reports (1996), para.25, p.226.

${ }_{18}$ See Article 2 (3) of ICCPR, (1966); Article 13 of European Convention on Human rights and fundamental freedoms (ECHR), as amended by Protocols Nos. 11 and 14, 4 November, (1950); and Article 2 of Convention against Torture and Other Cruel, Inhuman or Degrading Treatment or Punishment (CAT), 10 December, (1984), UNGA/A/RES/39/46.

${ }^{19}$ Advisory opinion of ICJ on case Concerning Legal Consequences of the Construction of a Wall in the Occupied Palestinian Territory, ICJ Reports (2004), para.106, p.136.

${ }^{20}$ These major human rights instruments include: Universal Declaration of Human Rights (UDHR), 10 December, (1948); International Covenant on Civil and Political Rights (ICCPR), 16 December, (1966); International Covenant on Economic, Social and Cultural Rights (ICESCR), 16 December, (1966); International Convention on the Elimination of All Forms of Racial Discrimination (ICERD), 21 December, (1965); Convention against Torture (CAT), 10 December, (1984); Convention on the Elimination of All Forms of Discrimination Against Women (CEDAW), 18 December, (1979); and Convention on the Rights of the Child (CRC), 20 November, (1989). 
instruments regional human rights system also creates human rights obligations on various regions. For instance, provisions of IHRL are binding in times of war under European Convention on Human Rights (ECHR). The ECHR is also useful in expanding the scope of extra-territorial application of IHRL. ${ }^{21}$

IHRL corresponds to IHL in times of armed conflict and apply complementary in such situations. For example, combatants and civilians right to life, right to fair trial, nondiscrimination, prohibition of degrading treatment is protected by IHRL instruments. ${ }^{22}$ The provisions of IHRL remain applicable always in all situations irrespective of armed conflict as pointed out by Secretary General of UN. IHRL applies everywhere and always. ${ }^{23}$ This argument is also advanced by human rights instruments. For example, the ICCPR states that:

"Each State Party to the present Covenant undertakes to respect and to ensure to all individuals within its territory and subject to its jurisdiction the rights recognized in the present Covenant". ${ }^{24}$

The regional human rights system and provisions of regional treaties also supports it. ${ }^{25}$ Given that States are obliged to respect provisions envisaged in treaties. For example, the Convention on the Rights of the Child (CRC) states that:

"States Parties shall respect and ensure the rights set forth in the present Convention to each child within their jurisdiction". ${ }^{26}$

IHRL also poses certain limitations and derogations in certain circumstances and existence of armed conflict is not necessary for application of IHRL. In an armed conflict IHL and IHRL mutually apply and their exist overlapping between both bodies of law in certain circumstances of armed conflict. For instance, common article 3 to Geneva Conventions overlaps with provisions of IHRL in times of armed conflict. The level of application of provisions of IHRL is low where IHL has provided specific protections. The overlapping of both bodies of law is also dependant on the nature and qualification of an armed conflict. ${ }^{27}$

\footnotetext{
21 See Hassan v. the United Kingdom, Application no. 29750/09, Grand Chamber Judgment, Council of Europe: European Court of Human Rights, 16 September, (2014) and Al-Skeini and Others v. United Kingdom, Application no. 55721/07, European Court of Human Rights, 7 July, (2011).

${ }^{22}$ Article 2, 3, 5, 7 and 10 of UDHR; Article 6, 7, 10 and 26 of ICCPR, Article 2,6 and 14 of ECHR, Article 2 of CAT; Article 1 of ICERD; Article 1 of CEDAW; and Article 2 of CRC.

${ }^{23}$ UN Secretary-General, "Respect for Human rights in armed conflicts”, UN Doc A/8052 (1970) 13, para 25.

${ }^{24}$ Article 2 (1) of ICCPR, (1966)

${ }_{25}$ Article 1 (1) of American Convention on Human Rights, 22 November, (1969); Article 1 of European Convention on Human rights, 4 November, (1950); Article 1 of African Charter on Human and Peoples' Rights, 27 June, (1981); and Article 3 (1) of Arab Charter on Human Rights, 15 September, (1994)

${ }^{26}$ Article 2 (1) of CRC, (1989)

27 David Kretzmer, "Rethinking Application of International Humanitarian Law in Non-International Armed Conflicts", Israel Law Review 42, p37.
} 
Thus States have human rights obligations to respect, promote, protect and fulfill rights of individuals. The justiciability of human rights is also important concern where human rights violations occur. Despite justiciability of human rights obligations, States as well as Non-state actors are bound by the provisions of IHRL and required to respect provisions of IHRL in times of armed conflict under customary IHRL. ${ }^{28}$ The universal nature of human rights may be considered and taken into consideration by states in all situations. ${ }^{29}$

\section{B. The Question of Limitations and Derogations under IHRL}

The provisions of IHRL diverge and converge with provisions of IHL. IHRL is applicable in all times whereas IHL is specific to armed conflict. It is general rule which distinguishes IHRL from IHL. However, there are certain exceptions, such as, limitations and derogations put by IHRL treaties. Scholars have explained it in detail. For example:

Limitation and derogation clauses in treaties have a similar function in the sense that both provide legal avenues for states to break free of obligations that would ordinarily constrain their actions. They are also similar in that neither permits states to ignore their human rights obligations altogether. However, one significant difference between the two is that derogations were designed to be applicable only in the exceptional case of a grave threat to the survival and security of a nation. The implication is that derogations were intended to be invoked as temporary measures. In contrast, limitation clauses apply across the spectrum, from everyday public order maintenance and policing strategies to national security and large-scale military actions. ${ }^{30}$

The limitations and derogations are subject to be legal and not otherwise. For instance, the ICCPR provides for the protection of the right to freedom of religion or beliefs, but states that the freedom to exercise this right can be subjected to such "limitations as are prescribed by law and are necessary to protect public safety, order, health, or morals or the fundamental rights and freedoms of others." 31

Although the ICCPR also recognizes freedom of expression and right to hold opinions without interference but these rights may be restricted. However, these are subject to limitations and restrictions in certain circumstances where necessary and legal. These may be

${ }^{28}$ D.A. Jeremy Telman, "Non-State Actors in the Middle East: A Challenge for Rationalist Legal theory", Cornell International Law Journal, (2013), p52.

${ }^{29}$ Report of the Human Rights Committee on Universality of Human rights and Cultural diversity, The Netherlands, (1998).

${ }^{30}$ Ryan Goodman, Henry J. Steiner and Philip Alston, International Human Rights in Context, 3rd edition Oxford University Press, Oxford, (2008), p385.

${ }^{31}$ Article 18(3) of ICCPR, (1966) and Article 9(2) of European Convention on Human Rights, (1950). 
limited if against public order or national security or against respect of rights of others. ${ }^{32}$ Further, ICCPR also poses limitations on freedom to choose residence and movement. ${ }^{33}$ It also extends to the right to freedom of association ${ }^{34}$ and the right of peaceful assembly. ${ }^{35}$

The purpose of limitations is to provide states with some flexibility in implementing some of the treaty rights. These limitations are also recognized by IHL. For instance, article 53 of the Fourth Geneva Convention prohibits the "destruction by the Occupying Power of real or personal property belonging individually or collectively to private persons, or to the State, or to other public authorities, or to social or cooperative organizations" with the exception, however, of situations "where such destruction is rendered absolutely necessary by military operations." 36

In this context, the other treaties of IHL also put limitations. Additional Protocol-II affirms that: "the displacement of the civilian population shall not be ordered for reasons related to the conflict unless the security of the civilians involved or imperative military reasons so demand." 37

On the other hand, under IHRL Derogations are allowed in circumstances, such as, in the cases of war or emergency. The provisions of ICCPR (discussed above) are more specific in this regard. Moreover, the regional treaties also allow derogations except African Charter. ${ }^{38}$ The rationale behind derogation is nothing that: "those human rights operate in times of normality, on the basis of harmony and cohesion between government and governed and are neither designed for nor adequate to control an armed conflict between government and dissident, armed or unarmed, elements of the population." 39

Thus Derogation is allowed only in exceptional circumstances and the other provisions of treaties remain applicable. These derogatory provisions do not withdraw application of other provisions of IHRL. Derogations are limited to those rights which are expressly enumerated in provisions of treaty and not vice-versa. For example, the right to life

32 Article 19 of ICCPR, (1966)

33 Ibid; article 12.

${ }^{34}$ Ibid; article 22.

35 Ibid; article 21

${ }^{36}$ Article 53 of Fourth Geneva Convention, (1949)

37 Article 17(1) of Additional Protocol-II, (1977)

${ }^{38}$ African Charter do not allow for derogations. However, these are allowed under American and European Convention. Country report of African Commission on Human and Peoples' rights, titled: "Seventeenth Annual Activity Report of the African Commission on Human and Peoples' Rights", (2003-2004), Online available at: <www.achpr.org/english/activity_reports/17th\%20REPORT\%20-FINAL,\%20Rev2,15dec2004,\%20EN.doc>, (Last accessed: 10 April, 2018).

${ }^{39}$ G. Draper, Reflections on Law and Armed Conflicts: The Selected Works on the Laws of War by the Late Professor Colonel G.I.A.D. Draper, OBE, edited by Michael A. Meyer and Hilaire McCoubrey, Martin Nijhoff Publishers, The Hague, (1998), p149. 
is non-derogable and protected under IHRL. The arbitrary killing and degrading punishment is also non-derogable and thus prohibited. ${ }^{40}$ The right to fair trial is also de facto nonderogable and protected. ${ }^{41}$ States are required to derogate exceptionally. It is given in human rights instruments. For example: article 4 of ICCPR states that:

"In time of public emergency which threatens the life of the nation and the existence of which is officially proclaimed, the States Parties to the present Covenant may take measures derogating from their obligations under the present Covenant to the extent strictly required by the exigencies of the situation, provided that such measures are not inconsistent with their other obligations under international law and do not involve discrimination solely on the ground of race, colour, sex, language, religion or social origin., ${ }^{, 42}$

For application of the provisions of IHRL, the HRC has also settled boundaries regarding derogations in times of armed conflict. It includes the measures of derogation and their implementation. ${ }^{43}$ The scope of application of derogatory provisions of IHRL is broad as compared to provisions of IHL. Generally IHL does not allow for derogation and the limitations posed by IHL are few whereas under IHRL the scope of application is wider. ${ }^{44}$ In the cases of derogations, there exist overlapping between IHL and IHRL.

\section{Core Human rights obligations of States in armed Conflict}

By virtue of humanity, IHRL poses obligations on states equally. States are primarily responsible for promotion and protections of fundamental human rights of individuals. States are also obliged to incorporate and legislate domestically and ensured to protect human rights provisions. The domestication of IHRL requires states to ensure human rights standards.

States have primary obligations to respect, protect and fulfill provisions of IHRL. In this context, the protection must be given to all at all levels on equal basis without any discrimination. States are not allowed to deprive any individual for enjoyment of human rights and subject to promote human rights obligations. States have obligation to promote equality and non-discrimination to all in all respects. For example, everyone has right to

40 Article 4(2) of ICCPR, (1966); Article 15(2) of European Convention on Human Rights and Fundamental Freedoms, (1950) and Article 27(2) of American Convention on Human Rights, (1969).

${ }^{41}$ General Comment No. 29 on States of Emergency (article 4), UN Doc CCPR/C/21/Rev.1/Add.11 (2001), para.16.

42 Article 4(1) of ICCPR, (1966).

${ }^{43}$ General Comment No. 29 on the length and extent of derogation measures, para 4.

${ }^{44}$ For example, Article 54 paragraph 2 of Additional Protocol-I, (1977) states that: "It is prohibited to attack, destroy, remove or render useless objects indispensable to the survival of the civilian population, such as foodstuffs, agricultural areas for the production of foodstuffs, crops, livestock, drinking water installations and supplies and irrigation works, for the specific purpose of denying them for their sustenance value to the civilian population or to the adverse Party, whatever the motive, whether in order to starve out civilians, to cause them to move away, or for any other motive.[...]". "In recognition of the vital requirements of any Party to the conflict in the defense of its national territory against invasion, derogation from the prohibitions contained in paragraph 2 may be made by a Party to the conflict within such territory under its own control where required by imperative military necessity." 
employment. Equal opportunities must be created for individuals and equal treatment must be given. The working conditions must be reasonable and not cruel.

States are required to utilize maximum available resources for working of individuals. States are also required to ensure protection in case of violation of human rights provisions. States are also required to ensure fulfillment by providing effective remedies to individuals in the case of violations. ${ }^{45}$ Thus the core human rights obligations are obligation to respect, protect and fulfill provisions of IHRL in the cases of an armed conflict along with other obligations under IHRL.

The obligation to respect requires that states must not interfere or curtail the enjoyment of human rights of individuals. States cannot take unpreventive measures against individuals in access of basic facilities. The obligation to protect requires states to protect and ensure protection of individuals in the case of human rights violation. Deprivation of rights is no longer allowed under IHRL. The obligation to fulfill requires that States must take positive actions for enjoyment of all fundamental human rights. It includes obligation to facilitate and obligation to provide.

States have obligation to protect victims within territory in the case of emergencies. ${ }^{46}$ Article 2(1) of the ICESCR spells out the obligation of States "to take steps, individually and through international assistance and cooperation ... with a view to achieving progressively the full realization of the rights recognized in the ... Covenant". A similar norm is contained in article 11(2) of the Covenant with specific regard to the right to freedom from hunger, to the effect that States shall take measures, individually and through international cooperation. Thus states have immediate and progressive obligations under IHRL for the protection of individuals in an armed conflict.

\section{The Question of Extraterritorial application of IHRL}

There are no inherent requisites for application of IHRL unlike IHL in armed conflict. Nevertheless, the application of IHRL is universal. ${ }^{47}$ States are bound to apply human rights treaties. IHRL is primarily applied by states within the territorial boundaries. This obligation is envisaged in human rights instruments. ${ }^{48}$

This obligation raises question that whether or not IHRL has extra-territorial applicability or in simple words Do human rights obligations extends outside jurisdiction of

\footnotetext{
${ }^{45}$ Maastricht Guidelines on Violations of Economic, Social and Cultural Rights, Maastricht, January 22-26, (1997).

${ }^{46}$ Resolutions of UNGA No: 43/131, second para; Resolution 45/100, third para; and Resolution 46/182, para. 4.

47 The General Assembly of UN has considered UDHR as a universal and common standard of achievement for all peoples and nations. G.A. Res. 217 (III) A, U.N. Doc. A/RES/217(III) (Dec. 10, 1948).

${ }^{48}$ Article 2(1) of ICCPR, (1966).
} 
State? To what extent provisions of IHRL applies to armed groups, non-recognized entities or in the context of war on terror? The answer is given by representatives of US in negative in the past decades. They held that obligations posed by ICCPR and CAT cannot be applied outside the territorial boundaries of State. ${ }^{49}$

However, later this view was changed. There exist international consensus that because of universality of IHRL, the provisions of IHRL apply extraterritorially or where is effective control of respective state. In other words where state exercises effective control, the provisions of IHRL will come into play. ${ }^{50}$ This argument is advanced by UNHRC, CCAT, ICJ, ECHR and national courts. ${ }^{51}$ It seems that the standard set by international and national bodies is effective control of respective state. It is common to all worldwide irrespective of territorial sovereignty and elaborates the content of application of human rights obligations extraterritorially. ${ }^{52}$

\section{ICJ on Jurisdictional application of IHRL}

Although both bodies of law, such as, IHL and IHRL are distinct from each other but both may apply together in particular situations. The former is purely designed for war whereas later applies in peace mostly and war as stipulated by the European Union Guidelines on promoting compliance with international humanitarian law. ${ }^{53}$ There exist interdependence and complementarity between both bodies of law. The parallel application of IHL and IHRL in an armed conflict is reaffirmed by ICJ in the cases of the Construction of the Wall in the Occupied Palestinian Territory and DRC v . Uganda. ${ }^{54}$

The Court emphasized on de facto application of IHRL. Even in the situation of belligerent occupation, the provisions of IHRL remain applicable. Article 42 of the Hague Reguations of 1907 sets the effective control standard. While having effective control, the

\footnotetext{
49 Letter from the Permanent Representative of the United States of America to the United Nations and Other International Organizations in Geneva, to the Office of the High Commissioner for Human Rights on 31 January, (2006), E/CN.4/2006/120 (Feb. 27, 2006)

50 Sarah H. Cleveland, "Embedded International Law and the Constitution Abroad", 111 Columbia Law Review 225,229 (2010), pp225-229.

51 Oona Hathaway, Elizabeth Nielsen, Aileen Nowlan, William Perdue, Chelsea Purvis, Sarah Solow and Julia Spiegel, "Human rights Abroad: When do Human rights treaty obligations apply extraterritorially", 43 Arizona State Law Journal $389,(2011), \mathrm{p} 13$.

52 Sarah H. Cleveland, "Embedded International Law and the Constitution Abroad", 111 Columbia Law Review 225, 229 (2010), p269.

${ }^{53}$ European Union Guidelines on promoting compliance with international humanitarian law, (2005) 0JC327/04, para. 12.

${ }^{54}$ Advisory opinion of ICJ on Legal Consequences of the Construction of a Wall in the Occupied Palestinian Territory , (2004) ICJ Reports 136 at 178, para. 106 (The Wall's case); Democratic Republic of the Congo v. Uganda, Case Concerning the Armed Activities on the Territory of the Congo, Judgment of 19 December, (2005), para. 216 (Congo vs. Uganda).
} 
acts done by occupying powers contrary to provisions of IHL and IHRL are of no effect. ${ }^{55}$ The Court in Walls case observed that the territory of Palestine is under belligerent occupation and IHL and IHRL applies to such situation. ${ }^{56}$

The court highlighted the violations of the provisions of IHL, such as, construction led to destruction and it is in violation of Articles 46 and 52 of the 1907 Hague Regulations and Article 53 of the GC-IV. In terms of IHRL, the Court finds out the violation of IHRL provisions and determined that construction of wall "impede the exercise by the persons concerned of the right to work, to health, to education and to an adequate standard of living", which are protected under IHRL particular in ICESCR. Moreover, the provisions of ICCPR are also violated, such as, freedom of movement under article 12 (1) of ICCPR and deprivation of right of freedom to choose residence. ${ }^{57}$ These violations cannot be justified on the basis of military necessity or humanity.

Another example in this context is Uganda Vs. Congo under which the people of Congo claimed for violations of IHL and IHRL in occupied parts of Congo by Uganda's forces $^{58}$ The ICJ has observed the violations of provisions of IHL and IHRL in Uganda Vs. Congo case and finds Uganda as responsible for violations of human rights obligations. ${ }^{59}$ Thus the ICJ clarifies the position of application of IHRL that it continues to apply along with IHL in times of armed conflict.

This position was also reaffirmed by the International Criminal Tribunal for the Former Yugoslavia (ICTY) that there is fusion between IHL and IHRL in times of an armed conflict in certain aspects. ${ }^{60}$ Further, the tribunal held that: "notions developed in the field of human rights can be transposed in international humanitarian law only if they take into consideration the specificities of the latter body of law". ${ }^{61}$

Thus keeping in view the decisions of International courts it is established that provisions of IHL and IHRL continues to apply in times of armed conflict. The former is the special law and only applies in armed conflict whereas the later also applies in armed conflict

\footnotetext{
55 Yoram Dinstein, “The International law of Belligerent Occupation and Human Rights", 8 Israel Yearbook of Human Rights, (1978), p142.

${ }_{56}$ The Wall's Case, para. 89.

${ }^{57} \mathrm{Ibid}$; at paras, 133-134.

${ }^{58}$ Congo vs. Uganda, paras 181-195.

59 Ibid; at para. 220.

${ }^{60}$ Prosecutor Vs. Dragoljub Kunarac and others, Case No: IT-96-23-T, Judgment of 22 February, (2001), para. 467.

${ }^{61} \mathrm{Ibid}$; at para. 471. 
depending upon the nature of the situation. In conclusion, both bodies of law apply together with complementarity. ${ }^{62}$

\section{Contemporary Challenges for States in Implementation}

There are certain challenges for states in implementation of human rights law in an armed conflict. These include:

The challenge of Extreme Hunger and poverty as poverty and hunger are a cause for violation of the provisions of IHRL. ${ }^{63}$ The other challenges include: The challenge of protection of victims in an armed conflict; the Challenge of Prevention of gross human rights violations in an armed conflict; the Challenge of protection of internally displaced persons; discrimination; weak institutions; unemployment; inequality; violence; promotion of human rights to all; protection of rights of individuals at national level; and the challenges of new warfare including terrorism and biotechnological weapons.

The biotechnological challenges include: human procreation; gene patenting (genome, human stem cells and other cell lines) and health care access for the poorest; interventions on the human body (therapeutic cloning, removals, management and sale of organs and tissues), end of life, prenatal or genetic diagnosis; knowledge of genetic traits. The provisions of IHRL are silent on the scientific development. However, the challenge of implementation of decisions of international and national courts is also a challenge. Further, the challenge how to deal with non-state actors or armed groups using new means and methods of war in an armed conflict is also a challenge.

\section{Conclusion}

To conclude, this article has analysed that the IHL and IHRL are bodies of International law which concerns with the protection of states as well as individuals. The former operates in times of armed conflict or war whereas later apply in peace as well as in armed conflict. The bulk of IHRL is enshrined in International treaties and instruments and protection is available to everyone on the basis of humanity. For instance, the UDHR states that "all human beings are born free and equal in dignity and rights". ${ }^{64}$

Although IHL is specific to armed conflict but the provisions of IHRL are also applicable and should be applicable in terms of its implementation. However, because of their different nature, in application there are certain conflicts between both bodies of law. Both

62 Alexander Orakhelashvili, "The Interaction between Human Rights and Humanitarian Law: Fragmentation, Conflict, Parallelism, or Convergence?”, The European Journal of International Law, Vol. 19 no. 1 (2008), p168.

${ }^{63}$ Human Rights Council Resolution A/HRC/RES/21/11.

${ }^{64}$ Article 1 of Universal Declaration of Human Rights, (1948), G.A. Res. 217 (III), U.N. Doc. A/801, 10 December, (1948). 
apply in times of armed conflict with complementarity and are mutually reinforce able. The core of the law of armed conflict is envisaged in Four Geneva Conventions of 1949 and Additional Protocols of 1977. The provisions of Human rights instruments, such as, UDHR, ICCPR and ICESCR are also applicable in armed conflict.

This article has revealed that because of universality of IHRL, the obligations are incumbent on States under IHRL in armed conflict. Even IHRL is applicable de facto in the case of belligerent occupation, prolonged occupation and other forms of occupation under customary IHRL. ${ }^{65}$ The entitlements given by IHRL are non-discriminatory, universal, inherent and inalienable for all individuals. In an armed conflict, the provisions of IHRL diverge and converge which means that derogation of rights is allowed only in exceptional and necessary circumstances. These limitations or derogations are envisaged in human rights treaties, such as, ICCPR and ICESCR. In terms of obligations of states in armed conflict, IHRL imposes obligation to respect, protect and fulfill fundamental human rights of individuals within territorial administration and demands domestication and progressive realization of such obligations by states.

Regarding application, it has established that the application of IHRL is universal and is not limited to states only but it also extends de facto to the elements outside state's jurisdiction. For example, IHRL also poses obligations on non-state actors, NGOs, armed groups and occupying powers. ${ }^{66}$ The de facto application of IHRL is advanced by ICJ in landmark decisions. For instance, the Nuclear weapons case, Congo vs. Uganda and the case concerning the Construction of Wall in occupied Palestine territories. However, in terms of implementation of IHRL states have certain challenges, such as, terrorism, poverty, inequality, discrimination, hunger, unemployment and gross violation of the provisions of IHRL.

\footnotetext{
${ }^{65}$ Advisory opinion of ICJ on Legality of the Threat or Use of Nuclear Weapons, Advisory Opinion, ICJ Reports (1996), para.25, p.226.

${ }^{66}$ The General Assembly of UN has considered UDHR as a universal and common standard of achievement for all peoples and nations. G.A. Res. 217 (III) A, U.N. Doc. A/RES/217(III) (Dec. 10, 1948).
} 